\title{
Fiqh Al-Muwāțanah: Nahdlatul Ulama's Interpretation About Citizenship
}

Muh. Sholihuddin

Universitas Islam Negeri Sunan Ampel, Surabaya msholihuddin@uinsby.ac.id

Article History:

\begin{tabular}{|l|l|}
\hline Received: May 21, 2021 & Accepted: November 19, 2021 \\
\hline Revised: October 04, 2021 & \\
\hline
\end{tabular}

\begin{abstract}
This article examines the influence and challenges of figh al-muwätanah in Indonesia. The discussion of this article focuses on a description of the pros and cons of the al-muwattinūn concept offered by Nahdlatul Ulama (NU) and the challenges faced in implementing it. The method used is a literature study with a historical and comparative approach, then analyzed using content analysis. The research findings show that al-muwätinūn as a sociopolitical concept is a new term that will not be found in the treasures of classical Islamic thought. Al-muwātinūn is a product of NU ulama's ijtihad as a response to the strengthening of takfiri in Indonesia. Al-muwaținūn contains values and teachings about equality, justice, and equality is a continuation of the mission brought by al-muwātinūn to form a tolerant and peaceful society by eliminating the mention of infidels non-Muslims. All Indonesian people have the same status, whether Muslim or nonMuslim, and there is no majority or minority. Al-muwāținūn is a form of figh typical of the archipelago. This idea has been started by previous Muslim thinkers who tried to contextualize Islamic law in Indonesia. On the other hand, the al-muwätinin concept shows NU's consistency in guarding the Unitary State of the Republic of Indonesia (NKRI).
\end{abstract}

Keyword: Fiqh al-Muwātanah; Nahdlatul Ulama; Citizen 


\begin{abstract}
Abstrak
Artikel ini mengkaji tentang pengaruh dan tantangan fiqh almuwāțanah di Indonesia. Diskusi artikel ini terfokus pada uraian tentang pro kontra tentang konsep al-muwāținūn yang ditawarkan oleh Nahdlatul Ulama (NU) dan tantangan yang dihadapi dalam pengimplementasiannya. Metode yang digunakan adalah studi pustaka dengan pendekatan historis dan komparatif, kemudian dianalisis dengan menggunakan analisis isi. Temuan penelitian menunjukkan bahwa al-muwāținūn sebagai sebagai sebuah konsep social politik merupakan istilah baru yang tidak akan ditemukan dalam khazanah pemikiran Islam klasik. Al-muwāținūn adalah produk ijtihad ulama NU sebagai respons paham takfiri yang menguat di Indonesia. Al-muwāținūn berisi nilai dan ajaran tentang kesataraan, keadilan, dan persamaan merupakan kelanjutan dari Misi yang dibawa oleh al-muwāținūn ini adalah terbentuknya sebuah masyarakat toleran dan damai dengan menghilangkan penyebutan kafir kepada non-muslim. Semua masyarakat Indonesia statusnya sama, baik muslim atau non-muslim, dan tidak ada mayoritas dan minoritas. Al-muwāținūn merupakan dari dari fikih khas nusantara. Gagasan ini telah dimulai oleh para pemikir Muslim sebelumnya yang mencoba mengontekstualisasikan hukum Islam di Indonesia. Di sisi lain, konsep al-muwāṭinūn ini menunjukkan konsistensi NU dalam mengawal Negara Kesatuan Republik Indonesia (NKRI).
\end{abstract}

Kata Kunci: Fiqh al-Muwāțanah; Nadlatul Ulama; Warga Negara 


\section{INTRODUCTION}

Coinciding with Eid al-Adha, Tuesday, July 20, 2021, Darsi's resident died in Wedoro Waru Sidoarjo. Most residents believe Darsi is a Christian even though the Identity Card (KTP) status is Islam. To the knowledge of the residents in the village, Darsi often attends "worship" carried out by Christian congregations. Hence, the residents refuse to have Darsi buried in the cemetery in the village. There was a debate between residents and their families, who are all Muslim. The family wanted Darsi to be buried in the village cemetery because his ID card status was Muslim. At the same time, the residents refused because, according to the "creed," a non-Muslim cannot be buried in a Muslim cemetery. ${ }^{1}$

Then several other cases, such as the religious conflict in Poso in 1992, the Sunni-Shia conflict in East Java in 2006, and the religious conflict in Bogor due to the construction of the Yasmin GKI 2000. ${ }^{2}$ In Pasuruan, three places of worship were destroyed by Hindus who live on the slopes of Mount Bromo carried out by unknown people. One of the places of worship is the holy place of Pinanditan Widodaren which is located in Tosari District, Pasuruan Regency, East Java. In Depok, in February 2020, the City Government banned Valentine's Day activities for school principals because it was against religious, social, and cultural norms. In 2019 in Surakarta, there was a rejection by residents of the plan to build a Child Development Center (PPA) for the Indonesian Christian Church. In 2020, there was

1 The author witnessed firsthand the events of the debate between families, village officials, and residents.

2 Ricky Santoso Muharam, "Membangun Toleransi Umat Beragama Di Indonesia Berdasarkan Konsep Deklarasi Kairo (Creating Religion Tolerance in Indonesia Based on the Declaration of Cairo Concept)", Jurnal HAM, Volume 11, Nomor 2, Agustus 2020: 270. http:/ / dx.doi.org/10.30641/ham.2020.11.269-283 
a ban on wearing the hijab by several hotels and restaurants in the Province of the Bangka Belitung Islands towards vocational school students and their employees. ${ }^{3}$

This phenomenon is an example of the many cases of intolerance and violence that occur in society. People often reject something that is considered different because it is not a class. At the same time, a citizen in the context of the state should be equal before the law, socially, politically, and culturally. If left unchecked, there is the potential for dangerous social conflict. It is essential to reformulate the most appropriate formula so that potential conflicts occur in closed societies so that synergy and social harmony are realized.

Indonesia is a big country. Based on data from the Central Statistics Agency (BPS) in 2010, the population reached 236,728,379 people, 1300 more ethnic groups, 652 regional languages, and six different religions. ${ }^{4}$ This plurality certainly has a high potential to clash if not appropriately managed. Therefore social interaction in a pluralistic society requires a bridge that can bring together differences to avoid conflicts. ${ }^{5}$

It is interesting to study the Alim Ulama National Conference (Munas) results and the Nahdlatul Ulama Grand Conference (Konbes) on February 27 - March 1, 2019, at the Miftahul Huda AlAzhar Islamic Boarding School, Banjar City, West Java, through the Bahtsul Masail Diniyah Maudluiyah Commission. Non-Muslim Indonesians cannot be called infidels but al-muwāținūn, namely

${ }^{3}$ Subhi Azhari dan Halili, Indeks Kota Toleran (IKT) Tahun 2020 (Jakarta: Pustaka Masyarakat Setara, 2020), 45-49.

${ }^{4}$ Badan Pusat Statistik (BPS), Kewarganegaraan, Suku Bangsa, Agama, dan Bahasa Sehari-hari Penduduk Indonesia Hasil Sensus Penduduk 2010 (Jakarta: Badan Pusat statistic, 2010), 7-11.

5 Wawan Gunawan Abdul Wahid, dkk., Fikih Kebhinekaan (Bandung: Mizan Pustaka, 2015), 15. 
citizens. The mention of al-muwātinūn is to avoid discriminatory theological attributions to citizens of other countries. Al-muwāținūn, this means that Muslims and non-Muslims are equal because they are both citizens. ${ }^{6}$

The concept of al-muwāținūn offered by Nahdlatul Ulama (NU) is a very progressive decision. The concept of al-muwāținūn has become an alternative perspective amid the strengthening of Islamic fundamentalist groups. This group often uses the term infidel to accuse other groups who reject the formalization of Islam. The term infidel, which then not infrequently causes social offenses that have the potential for conflict in society.

This study aims to examine the influence and challenges of fiqh al-muwattanah in Indonesia. This study focuses on the pros and cons of the al-muwattinūn concept offered by $N U$ and the challenges faced in implementing it. Many studies on the relationship between Islam and Indonesia have been carried out. For example, Hasbi ashShiddiy with "Indonesian fiqh," Hazairin with "National School," Munawir Sjadzali with "Reactualization of Islamic law," Abdurrahman Wahid (Gus Dur) "Indigenization of Islam," and Masdar F. Mas'udi "Zakat as Tax." Then "Fiqh of Diversity," which reviews the thoughts of Ahmad Syafi'i Maarif. However, figh almuwattanah is different because it was born while strengthening conditions for intolerant groups.

\section{RESEARCH METHODS}

The method used in this article is a literature study. Therefore, the data used are obtained from various readings, books, journals,

6 Kompas News, "NU Usul Non-Muslim di Indonesia Tak Disebut Kafir", kompas.com, Published 01

Maret 2019, https:/ / regional.kompas.com/read/2019/03/01/12404031/nu-usul-non-muslim-diindonesia-tak-disebut-kafir?page=all, diakses 01 Nopember 2020. 
and other library sources. Moreover, in data collection, used documentation method. With this method, researchers try to collect the necessary data, either through primary or secondary.

Furthermore, the approach used is historical and comparative. ${ }^{7}$ The historical approach explores the relationship between almuwattanah offered by NU and previous studies on the concept of NU's nationality. Meanwhile, a comparative approach is used to compare al-muwātanah with other concepts about Islam and Indonesianness, which were previously the discussion themes by Indonesian Islamic thinkers.

Furthermore, the approach used is historical and comparative. A historical approach describes the relationship between emerging concepts or ideas with previous concepts or ideas. This study was conducted using a historical and comparative approach. The historical approach is used to trace the relationship between almuwattanah offered by NU and previous studies on the concept of NU's nationality. Meanwhile, a comparative approach is used to compare al-muwātanah with other concepts about Islam and Indonesianness, which have previously been the theme of discussion by Indonesian Islamic thinkers.

The data obtained were then analyzed using content analysis and hermeneutics. Content analysis is used to analyze written data in the form of communication content. ${ }^{8}$ The contents of communication referred to in this study are concepts, opinions, theories, and principles contained in books, journals, research works, or other writings published in various media. At the same time, hermeneutics

7 Sri Haryanto, "Pendekatan Historis dalam Studi Islam", Manurul Qur'an: Jurnal Ilmiah Studi Islam, VOL 17 NO 1 (2017), 131, https:/ / doi.org/10.32699/mq.v17i1.927

8 Jalaluddin Rakhmad, Metode Penelitian Komunikasi (Bandung: Remaja Rosda Karya, 1989), 122. 
is used to view history as a living dialogue between the past, present, and future. ${ }^{9}$

\section{RESULTS AND DISCUSSION}

\section{al-Muwāținūn: Debate and Controversy}

Al-muwäținūn, which means citizen, 10 is often contrasted with infidel in the context of the state. Käfir in question is different in faith from Muslims. Said Hawa gives an understanding that infidels are people who deny the truth of Islam. ${ }^{11}$ Moreover, this term was first used to designate some residents of Mecca who insulted the Prophet, and then in Medina, it was also shown to the Ahl al-Kitāb. ${ }^{12}$ The point is that unbelief is an act that leads to a lie or denial of Allah and His Messenger, especially to the Prophet Muhammad with the teachings he brought. ${ }^{13}$

The history of disbelief (takfir) that occurred first appeared during the tahkim event carried out by the Khawarij as a form of cursing someone for not believing ( $k a \overline{f i r}$ ) or condemning someone as a käfir. ${ }^{14}$ Since that time, the culture of infidel infidelity has been known in the Muslim community. Then this was followed by Ali's followers, known as Shi'ah, who punished the disbelievers against

${ }^{9}$ Abdullah A. Talib, Filsafat Hermeneutika dan Semiotika (Palu: LPP-Mitra Edukasi, 2018), 44 .

10 Fitriani dan Siti Aisyah, "Konsep Kafir dalam Pandangan Nahdlatul Ulama (NU) dan Forum Umat Islam (FUI) Sumatera Utara", Studia Sosia Religia, Volume 2 Nomor 2, Juli-Desember 2019, 37. http:/ / dx.doi.org/10.51900/ssr.v2i2.6485

11 Said Hawa, Al-Islam, Terj. Abdul Hayyi al-Kattani dkk, (Jakarta: Gema Insani Press, 2004), 288-289.

12 Farid Esack, Membebaskan Yang Tertindas: Alquran, Liberalisme, Pluralism, Terj. Watung A. Budiman (Bandung: Mizan, 2000), 180.

${ }^{13}$ Abdul Aziz Dahlan (et.al), Ensiklopedi Hukum Islam, Jilid 3 (Jakarta: Ichtiar van Hoeve, 1996), 856.

14 Toshihiko Izutsu, Konsep Kepercayaan dalam Teologi Islam (Yogyakarta: Tiara Wacana Yogya, 1994), 6. 
those not from their group. ${ }^{15}$ The Khawarij, with the motto lā hukma illā lillāh (no law but Allah's law), punishes anyone who does not adhere to the Qur'an as a käfir. ${ }^{16}$ Assuming an infidel in Arabic terms is called takfir - the mașdar (noun) form of the verb kaffara-yukaffirutakfiran-is kufr, accusing kufr, or infidel (considering/looking at infidel). 17

The consequences of understanding the term kâfir like this will impact the state's life because it has severe implications in the pattern of relations between citizens. Calling käfir to non-Muslims seems negative and not good in a nation-state like Indonesia because basically all citizens are the same. It is not uncommon for accusations of kāfir to be made against fellow Muslims. Allegations of kāfir like this are part of human rights crimes. ${ }^{18}$

Before choosing the nation-state as a form of state, national leaders first debated the relationship between Islam and nationalism. Natsir believes that the struggle for independence is so that Islamic rules and structures can be applied for the safety and dignity of Muslims. Therefore, Indonesia must become an Islamic State. Soekarno rejected this view of Natsir. According to Soekarno, such an assumption will only create a sense of discrimination, especially among non-Muslims. Soekarno initiated nationalism in the form of a democratic state. ${ }^{19}$ In a democratic country, the highest sovereignty is in the hands of the people, and the people have the same rights,

\footnotetext{
${ }^{15}$ Ibnu Sulaiman, Anda Muslim atau Kafir?, cet. 2 (Jakarta: Arista,1994), 12.

${ }_{16}$ Philip K. Hitti, History of the Arabs (London: The MacMillan Press, 1974), 181183.

17 Mahmud Yunus, Kamus Arab Indonesia (Jakarta: Yayasan Penyelenggara Penterjemah Pentafsir al-Qur'an, 1973), 378.

18 Mohammed Yunis, Politik Pengkafiran dan Petaka Kaum Beriman, Terj. Dahyal Afkar (Yogyakarta: Nuansa Aksara, 2006), xxii.

19 Arskal Salim, Challenging The Secular State: The Islamization of Law in Modern Indonesia (Hawa'i: University of Hawai'i Press, 2008), 74.
} 
opportunities, and voices in regulating government policies. ${ }^{20} \mathrm{~A}$. Hassan condemned Soekarno's view. He called nationalism jāhiliyyah or 'așābiyyah (ethnicity), contrary to Islamic teachings because there is a tendency to deify the nation. This model of nationalism must be able to lead to acts of shirk. ${ }^{21}$

Against this background, the concept of al-muwātinūn offered by NU found its momentum. Against this background, the concept of al-muwaținūn offered by NU found its momentum. Deputy Chairperson of the Bahtsul Masail Institute for the Nahdlatul Ulama (PBNU) Executive Board, Abdul Moqsith Ghazali, explained the importance of using the term infidel. The term kafir is often used by groups or individuals to refer to other groups or individuals different from their religious beliefs. Even the term infidel is also often used to designate other fellow Muslims. ${ }^{22}$ Said Aqil Siraj, General Chairperson of PBNU, explained that the state of Indonesia. With al-muwattanah system (nation-state) is not known as an infidel. All citizens are equal in the view of the constitution. The term infidel only occurs when the Prophet SAW. was in Mecca, while in Medina the Prophet. Use non-Muslim terms. ${ }^{23}$ Non-Muslims in the Unitary State of the Republic of Indonesia (NKRI) do not meet the requirements of the term kafir mentioned in the books of fiqh. Indonesia is not an Islamic State, so these terms are inappropriate when referring to non-Muslims in Indonesia. ${ }^{24}$ In this case, al-

\footnotetext{
${ }^{20}$ Rapung Samuddin, Fiqih Demokrasi (Jakarta: Gozian Press, 2013), 164.

${ }^{21}$ Ahmad Hassan, Islam dan Kebangsaan, dalam Tiar Anwar Bachtiar (ed.), Risalah Politik A. Hassan (Jakarta: Pembela Islam Media, 2013), 114.

22 Kompas News, NU Usul Non Muslim di Indonesia Tak Disebut Kafir", Published 01 Maret 2019, https:/ / regional.kompas.com/read/2019/03/01/12404031/nu-usul-non-muslim-diindonesia-tak-disebut-kafir?page=all, diakses 01 Nopember 2020. 38.

${ }^{23}$ Fitriani dan Siti Aisyah, "Konsep Kafir dalam Pandangan Nahdlatul Ulama..., 24 Ibid., 37.
} 
Ghazali stated that to disbelieve in someone is not easy and cannot be connected in all things. Even infidel results in the opening of several legal doors in shara', causing his property to be confiscated, and his blood is lawful and will also be eternal in hell. ${ }^{25}$

The emergence of al-muwaținūn later became a reasonably exciting debate. Responses, both individual and organizational, emerged to the public in response to the concept of NU's almuwaținūn. If mapped, there are two categories, namely; first, supporters (pros). The General Chairman of Muhammadiyah Youth, Sunanto, agrees with NU which prohibits infidel behavior to other groups. He argues that it is not permissible to corner people who already have their own beliefs. They need to understand the difference. There is no need to justify that they are infidels, let alone say it in public. ${ }^{26}$ According to Jusuf Kalla, according to aqidah, adherents of religions outside Islam are indeed called infidels. However, in the life of Indonesian society, there must be a softer word.

Moreover, the term non-Muslim was chosen because it is gentler than käfir. ${ }^{27}$ Guntur Romli, a politician from the Indonesian Solidarity Party (PSI), stated that calling non-Muslims unbelievers is hate speech, even though the term infidel is from the Qur'an; second, cons. Fahri Hamzah, Deputy Speaker of the Indonesian House of Representatives, stated that infidel is a term in the holy book.

${ }^{25}$ M. Taib Thahor Abdul Mu'in, Ilmu Kalam (Jakarta: Widjaya, 1997), 80.

26 Tirto News, "Kata Pemuda Muhammadiyah Soal Usul NU Tak Sebut Kafir ke Non-Islam", Tirto.id, Release 1 Maret 2019, https://tirto.id/kata-pemudamuhammadiyah-soal-usul-nu-tak-sebut-kafir-ke-non-islam-didc, diakses 02 Agustus 2021.

27 Medcom News, "JK: Nonmuslim Sebutan Lembut Kafir, Medcom.id, Release 12 Maret 2019, https:/ / www.medcom.id/nasional/peristiwa/Obzqy4dNjk-nonmuslim-sebutan-lembut-kafir, diakses 02 Agutus 2021. 
Therefore it cannot be amended. ${ }^{28}$ Eggy Sujana, a Muslim activist, disapproves of replacing the term infidel with non-Muslim. The reason is that the Qur'an itself mentions people who do not believe as unbelievers, for example, in the letter al-käfirūn. In Sürah al-Tahrìm, verse 9 ordered the Prophet SAW. to be rigid on the disbelievers and hypocrites. Substitution of the expression infidel to non-Muslim is not a teaching of Islam. Wawan Hari Purwanto explained that constitutionally the replacement was no problem, to respect the public sphere. The reason is to strengthen the spirit of togetherness in building the nation. ${ }^{29}$ Then the Islamic Community Forum (FUI) stated that it did not agree with NU. FUI considers this to be against religion and even accuses the concept of al-muwātinūn of being politically charged. ${ }^{30}$

Observing the debate between those who support and those against the concept of al-muwātinūn, the majority are not supported by a comprehensive academic narrative, except for Din Syamsuddin, the former chairman of PP Muhammadiyah. He wrote eleven points in response to the concept of al-muwatitinun. Among the most important is that the concept of al-muwattanah is a concept that has long been implemented in Indonesia. So far, the stability and harmony in Indonesia are the fruit of mutual agreement, which is based on co-existence, tolerance, and cooperation among the nation's

28 Suara News, "Pro Kontra Penghapusan Panggilan Kafir untuk Non Muslim", Suara.com, $\quad 07$ Release 2019, https://www.suara.com/news/2019/03/07/073000/pro-kontra-penghapusanpanggilan-kafir-untuk-non-muslim?page=all, diakses 02 Agustus 2021.

29 PTIQ News, "Polemik Kafir Atau Non Muslim Terjawab Dalam Seminar Nasional di Institut PTIQ Jakarta", ptiq.ac.id, Received 14 Maret 2019, https:/ / ptiq.ac.id/2019/03/15/polemik-kafir-atau-non-muslim-terjawab-dalamseminar-nasional-di-institut-ptiq-jakarta/, diakses 02 Agustus 2021.

30 CNN Indonesia News, "Berasal dari Alquran, Kata 'Kafir' Bukan Bentuk Penghinaan pada Non-Muslim, cnnindonesia.com, Realease 2 Maret 2019, https:/ / www.cnnindonesia.com/nasional/20190302165124-32-374019/fui-sebutfatwa-nu-non-muslim-bukan-kafir-bermotif-politis, diakses 02 Agustus 2021. 
children. Therefore, clashing the term muwāțin with käfir is inappropriate because the contexts of the two are different. Kafir is in the theological-ethical category, while muwātin is in the sociopolitical category. ${ }^{31}$

Din Syamsuddin's view above aligns with the motive behind the birth of the al-muwātinūn concept. The use of muwātinūn does not revise the concept of faith but only applies in the public sphere (mu'amalah wataniyah). ${ }^{32}$ Mentioning non-Muslims in the public sphere is only an inappropriate form of theological violence. The concept of almuwaținūn means providing equal space for all citizens, both ethnicity, ethnicity, and religion. 33

M. Khalid Syeirazi said that the emergence of the terminology of al-muwāținūn departs from whether it is appropriate to call nonMuslims infidels. At the same time, Indonesia is not an Islamic State? The mushäwirin, which consisted of NU scholars and intellectuals at the Bahtsul Masail Forum, ${ }^{34}$ still used the term infidel to refer to nonMuslims because the reference books used as a guide used the term infidel. After a reasonably complicated debate, the term musalimin

31 Karna News, "M. Din Syamsuddin: Seputar Polemik Tentang Kafir", karna.id, Release 7 Maret 2019, https:/ / karna.id/m-din-syamsuddin-seputar-polemik-tentang-kafir/, diakses 02 Agustus 2021

${ }^{32}$ M. Kholid Syeirazi, "Tentang Non-Muslim Bukan Kafir”, nu.co.id, Release, 02 Maret 2019, https://www.nu.or.id/post/read/103224/tentang-non-muslim-bukankafir, diakses 02 Agustus 2021.

33 Republika News, "Said Aqil Jelaskan Perbedaan Kafir dan Non-Muslim, $\begin{array}{llll}\text { republika.or.id, } & \text { Release, } & \text { Maret }\end{array}$ https:// www.republika.co.id/berita/pnogps409/said-aqil-jelaskan-perbedaan-kafir-dannonmuslim, diakses 02 Agustus 2021.

34 The Bahtsul Masail Forum is the highest forum for the organization whose decisions can be implemented by NU residents. This forum is managed and coordinated by the NU Bahtsul Masail Institute (LBM) by involving many scholars and intellectuals with different scientific backgrounds. The purpose of this forum is that ijtihad jama'i (collectively) can be carried out properly. Muh. Sholihuddin, "Kontruksi Fikih Kebangsaan Nahdlatul Ulama (Kajian terhadap Peran NU dalam Perspektif Fiqh Siyasah)", Al-Qanun: Jurnal Pemikiran dan Pembaharuan Hukum Islam, Vol. 24, No. 1, Juni 2021, 117. DOI: https:// doi.org/10.15642/alqanun.2021.24.1.85-121 
emerged, an effort from all parties to build a commitment to care for and protect each other. However, when the results were presented in front of the Plenary Session of the Bahtsul Masail Diniyah Maudluiyah Commission, Said Aqil Siraj suggested that musālimin be replaced with muwātinūn, which means citizens. Muwāținūn is a derivation of the word al-watan which means nation. This concept requires that all citizens are the same without differences. There is no majority or minority. What applies is the principle of equality before the law. ${ }^{35}$

Regardless of agreeing or not with the concept of al-muwāținūn, NU's offer further emphasizes its national role towards the Unitary State of the Republic of Indonesia (NKRI), where Pancasila is the basis of the state the 1945 Constitution (UUD) as the constitution. Historically, the role of nationality can be traced through the contribution of NU since before and after independence. In 1936, through the NU Congress in Banjarmasin, Indonesia, under Dutch rule, established the archipelago as dār al-Islām. ${ }^{36}$ The term dār alIslām is used not for political purposes but socio-religious interests. This term is NU's response to the status of an unidentified corpse, whether a Muslim or a non-Muslim. With dār al-Islām, the body was judged to be a Muslim. In addition, dār al-Islām refers to the obligation of Muslims to maintain order together. ${ }^{37}$ On August 18, 1945, NU, through Wahid Hasyim, who was directly involved in the Indonesian Independence Determination Committee Meeting (PPKI), unanimously accepted the abolition of the seven words in the Jakarta

${ }^{35}$ M. Kholid Syeirazi, “Tentang Non-Muslim Bukan Kafir”, nu.co.id, Release, 02 Maret 2019, https://www.nu.or.id/post/read/103224/tentang-non-muslim-bukankafir, diakses 02 Agustus 2021.

${ }^{36}$ M. Ali Haidar, Nahdatul Ulama dan Islam di Indonesia, Pendekatan Fiqih dalam Politik (Jakarta: Gramedia, 1998), 4.

${ }^{37}$ Muh. Sholihuddin, “Kontruksi Fikih Kebangsaan Nahdlatul Ulama..., 106. 
charter "with the obligation to carry out Islamic law for its adherents. "38 In 1945, NU issued a jihād resolution (October 22, 1945) which contained the mandatory law for Muslims to fight to defend the Republic of Indonesia. That struggle was part of jihād fi sabililläh. ${ }^{39}$ In 1983 in Situbondo through the National Alim Ulama National Conference, NU accepted Pancasila as the basis of the state, and Islam was maintained as the faith. ${ }^{40}$ One year later, in 1984, NU included the results of this National Conference in its Articles of Association (AD/ART). ${ }^{41}$ At the 30th Congress in 1999 in Kediri, it was decided that non-Muslims in an emergency could be elected as leaders. ${ }^{42}$

This explanation illustrates how NU, as a religious organization from the beginning, has become an inseparable part of forming the Republic of Indonesia. The decisions made are in solid synergy with the nation-state concept where religion is not an obstacle to uniting a pluralistic nation like Indonesia. Religion has become the basis for uniting ethnic, tribal, and religious differences. Moreover, almuwātinūn as a social, political, and legal concept, historically, is not surprising. Religion must also be able to play a role in building just and tolerant humanity. ${ }^{43}$ This fact shows the consistency of NU in guarding the Unitary State of the Republic of Indonesia.

${ }^{38}$ Ibid., 93-94.

${ }^{39}$ Ibid., 110.

${ }^{40}$ Martin Van Bruinessen, NU Tradisi Relasi-Relasi Kuasa Pencarian Wacana Baru (Yogyakarta: Elkis,1994), 76.

${ }^{41}$ Muh. Sholihuddin, “Kontruksi Fikih Kebangsaan Nahdlatul Ulama..., 109.

42 Salah Mahfud, Solusi Hukum Islam: Keputusan Muktamar, Munas dan Konbes NU 1926-2004, Cet. III (Kudus: Khalista, 2007), 211.

43 Abd. Rohim Ghazali, "Kerukunan Antarumat dan Peran Ulama" dalam Andito (ed.), Atas Nama Agama: Wacana Agama dalam Dialog "Bebas" Konflik, (Bandung: Pustaka Hidayah,1998), 329. 


\section{Archipelago Fiqh: Fiqh al-muwātanah and Fiqh of Diversity}

The discourse on the relationship between Muslims and nonMuslims is closely related to religion and the state. There are three views on this matter, namely, the First, integralists. Religion and the state (al-Islām dīn wa daulah) are unified and cannot be separated. ${ }^{44}$ Islam is not just a creed but also sharia, religion (al-din) and state (daulah), truth (al-haq) and strength (al-quwwah), worship ('ubüdiyyah) and leadership (imāmah), manuscripts (mușhaf), and war (al-jihädah); 45 second, secular. Religion and state are different entities. Muhammad was only a prophet sent for religious purposes, not a political leader, and was not sent to form a state. The formation of the state adapts to the times; ${ }^{46}$ and third, symbiosis. Religion and the State need each other. Religion needs the state to develop and vice versa. Naș alone does not determine the state's form, but in naș commonly found on ethical-moral teachings related to the pattern of human relationships, such as freedom, equality, and fraternity (brotherhood). ${ }^{47}$

The difference is because the texts (Qur'an and hadith) do not explain in detail the form of the state (government), only provide basic principles in managing the state such as the principles of deliberation (shurā) and justice (al-'adl), ${ }^{48}$ so that in Islamic history, the form of the state has varied with the times. After the Prophet or the period of al-Khulafā 'al-Rashidūn, the Sahabat made ijtihād form a State so that the election process of Abu Bakr, Umar, Uthman, and

${ }^{44}$ Arskal Salim, Challenging The Secular State..., 17.

45 Yusuf al-Qardawi, Pedoman Bernegara Dalam Perspektif Islam, Terj. Kathur Suhadi (Jakarta: Pustaka Al Kautsar, 1999), 35.

46 Ibid., 29.

47 Musda Mulia, "Negara Islam - Pemikiran Politik Hosen Haikal”, (Disertasi-IAIN Syarif Hidayatullah, Jakarta 1997), 289-290.

48 Bahtiar Effendy, Re-Politisasi Islam: Pernahkah Islam Berhenti Berpolitik? (Bandung: Mizan, 2000), 76. 
Ali different and adjusted according to their respective eras. After the era of al-Khulafa 'al-Rashidun, a very different country from the friend's era emerged. After the al-Khulafä' al-Rashidūn, a very different state emerged like the Umayyads, the Abbasids, the Ottoman Empire. During this period, the leadership transition process is carried out in an inherited way. Then enter the modern era where the leadership transition process no longer uses inheritance but a democratic way, namely choosing based on the individual abilities of future leaders.

This change shows that the issue of state and leadership is purely ijtihädiyah, where conditions and circumstances significantly affect its form and lead to differences of opinion among scholars, as explained above. In this context, Indonesian Muslim thinkers, such as Abdurrahman Wahid (Gus Dur), Nurcholis Madjid, Syafi'i Ma'arif, and others, came up with their ideas about the relationship between religion and the state. Gus Dur believes that practicing religion does not have to be formalized and ideologically Islamic. Islamic progress will be achieved if Islam develops culturally. ${ }^{49}$ Abdurrahman stated that he had felt in vain in his search for an Islamic state all his life. Gus Dur concluded that Islam does not exist how the state should be created and maintained.50 Likewise with Nurcholis Madjid considers religion and the state not essential. The emergence of the desire to establish an Islamic State is nothing more than an apologetic attitude in responding to Western ideologies such as democracy, socialism, communism, and other ideologies. ${ }^{51}$ In his view, Islam should be treated as moral teaching capable of giving

${ }^{49}$ Abdurrahman Wahid, Islamku, Islam Anda, Islam Kita, (Jakarta: Wahid Institute, 2006), xv.

${ }^{50}$ Ibid., 81.

${ }^{51}$ Nurcholis Madjid, “Menyegarkan Paham Keagamaan di Kalangan Umat Islam Indonesia," dalam Islam, Kemoderenan dan Keindonesiaan (Bandung: Mizan, 1987), 253. 
meaning to the ever-evolving process of socio-political change. ${ }^{52}$ Syafi'i Ma'arif considered that an Islamic State was no longer needed. The most important thing to strive for is the purpose of the state being formed, namely justice and prosperity. ${ }^{53}$ Afifuddin Muhajir, as quoted by Ghazali Said, that substantially, whatever system adopted by the state, if it can realize amr ma'rüf nahy munkar in the form of building equality, justice, deliberation, freedom, and supervision of the people, the country can be called an Islamic State. ${ }^{54}$

The critical point of the view of the Muslim thinker is that Islam as a religion must be placed as a spirit, values, and ethics in building the state. The formalization of Islam will distort the mission of Islam itself as the religion of rahmah $l i$ al-'älamin. In this way, Islam becomes a religion that unites humanity, fights for justice and human rights regardless of human background. Islam is a co-existence across borders, religions, and ethnicities. Pre-existence is about the projection of a life that goes hand in hand with manners, peace, and mutual understanding. 55 Said Aqil Siraj (Chairman of PBNU) stated that pluralism is a sunatullāh which, even though it occurs, is just as the heavens and the earth are. Denial of pluralism also means disobedience to God's will. 56

52 Dedy Djamaluddin Malik dan Idi Subandy Ibrahim, Zaman Baru Islam Indonesia; Pemikiran dan Aksi Politik Abdurrahman Wahid, M. Amien Rais, Nurcholis Madjid, Jalaluddin Rakhmat, Cet. I (Bandung: Zaman Wacana Mulia, 1998), 168.

53 Ahmad Syafii Maarif, Islam dan Pancasila sebagai sebagai Dasar Negara, Studi tentang Perdebatan dalam Konstituante (Jakarta: Pustaka LP3ES, 2006), 18.

54 Imam Ghazali Said, "Intelektualitas KH Afifuddin Muhajir", dalam KH. Afifuddin Muhajir: Faqih Ushuli dari Timur, Abdul Moqsith Ghazali (Penyinting) (Malang: Inteligensia Media, 2021), 9.

${ }_{55}$ Muhammad Makmun Rasyid, "Islam Rahmatan Lil Alamin Perspektif KH. Hasyim Muzadi", Episteme, Vol. 11, No. 1, Juni 2016, 107, https://doi.org/10.21274/epis.2016.11.1.93-116

56 Said Aqil Siradj, Islam Kebangsaan; Figh Demokratik Kaum Santri (Jakarta: Pustaka Ciganjur, 1999), cet. 1, hal. 203. 
The idea of the concept of al-muwatitinun is another form of the idea of archipelago Islam. Afifuddin Muhajir (Rais Syuriah PBNU) stated that it is a religion that grows, develops, and lives in the archipelago due to the dialectic between the texts of Islamic teachings (Quran and hadith) with local realities and culture. ${ }^{57}$ Mustofa Bisri (Rais Syuriah PBNU) said that archipelago Islam is a form of Islam that is rahmah li al-'alamin. Archipelago Islam is a terminology born from the womb of Islam and developed with friendliness, peace, and shade. ${ }^{58}$ So Islam in the archipelago is an Islamic teaching that is friendly with local practices. ${ }^{59}$ On the other hand, according to Burhanuddin Muhtadi, the idea of archipelago Islam is a form of resistance to Islamic fundamentalist groups, such as the Islamic Defenders Front (Front Pembela Islam, or FPI) and Hizbut Tahrir Indonesia (HTI). 60

The concept of al-muwātinūn, often called the figh of nationality (figh al-muwätanah), is in line with the fiqh of diversity. The difference is, figh al-muwātanah comes from NU, while fiqh on diversity comes from Muhammadiyah. However, both have a way of viewing the same in view Islam. The emergence of these two fiqh models is a response to strengthening the takfiri ideology that has begun to manifest in Indonesia. Both provide responsibility for critical issues,

57 KH. Afifudin Muhajir, "Meneguhkan Islam Nusantara untuk Peradaban Indonesia dan Dunia", makalah disampaikan pada Seminar Pra Muktamar NUke-33 di Asrama Haji Makassar, 22 April 2015.

58 Ahmad Sahal, Islam Nusantara, dari Ushul Figh hingga Paham Kebangsaan (Bandung: Mizan, 2015), 15.

59 Faried F. Saenong, "Nahdlatul Ulama (NU): A Grassroots Movement Advocating Moderate Islam", in Handbook of Islamic Sects and Movements, Ed. Muhammad Afzal Upal and Carole M. Cusack (Published by Brill, 2021), 145.

60 Marcus Mietzner and Burhanuddin Muhtadi, "The Myth of Pluralism: Nahdlatul Ulama and the Politics of Religious Tolerance in Indonesia", Contemporary Southeast Asia: A Journal of International and Strategic Affairs, Vol. 42, No. 1 (April 2020), 64-65. DOI: $10.1355 / \operatorname{cs} 42-1 c$ 
such as citizenship, social relations between diverse groups, and political leadership.

In 2015, a book with the title "Figh of Diversity" was published. In his statement in the book, it was written that the book "Figh of Diversity" is a series of publications to celebrate the 80 years of Ahmad Syafi'i Maarif (ASM) published by Mizan Media Utama Bandung. According to Fajar Riza, Director of the Maarif Institute, stated:61

"The figh of diversity opens a new interpretation of issues imbued with inclusive national awareness that is following the goals of the state according to the Qur'an and Hadith. The Jurisprudence of Diversity is also the antithesis of the growing threat of intolerance and sectarianism in recent years. Violence and sectarian conflicts in the Middle East that have not yet receded must be a mirror for Indonesia to not fall into the same hole. Cultivating an open and non-discriminatory religious understanding, especially in education and the younger generation, will stem the increasingly worrying symptom of misdirection (takfirism)".

Long before the emergence of fiqh al-muwātanah and fiqh of diversity, several Islamic thinkers in Indonesia had begun to look for a uniquely Indonesian fiqh formula, such as Hasbi ash-Shiddiy in the 1940s who initiated "Indonesian fiqh,"62 and Hazairin in the 1950s with the concept of "National School."63 In the 1980s, some Islamic thinkers reform Islamic law in Indonesia, such as Munawir Sjadzali with the concept of "Re-actualizing Islamic law,"64

${ }^{61}$ Fajar Riza Ul Haq, "Sambutan Maarif Institut", Fikih Kebinekaan (Bandung: Mizan Media Utama, 2015), 9.

${ }^{62}$ Hasbi Ash Shiddieqy, Syari'at Islam Menjawab Tantangan Zaman (Yogyakarta: IAIN Sunan Kalijaga, 1961), 24.

63 Hazairin, Hukum Kewarganegaraan Nasional, Edisi ke-3 (Jakarta: Tintamas, 1982), 6.

${ }^{64}$ Munawir Sjadzali, "Reaktualisasi Ajaran Islam”, dalam Polemik Reaktualisasi Ajaran Islam, ed., Iqbal Abdurrauf Sainima (Jakarta: Pustaka Panjimas, 1980), 1. 
Abdurrahman Wahid (Gus Dur), with the concept of "indigenization of Islam," and Masdar F. Mas'udi carry the theme "Zakat as a Tax."65

The description above provides a clear picture that the efforts of Islamic thinkers in Indonesia to make Islamic law follow the conditions in Indonesia continue to be carried out because Islamic law is flexible according to the context of its era. Following the rules of fighiyyah, changing a law should adjust to the situation, condition, time, and place (taghayyuru al-ahkām bi taghayyuri al-azmināti wa alamkinäti). ${ }^{66}$ So fiqh al-muwātanah, fiqh of diversity, fiqh of Indonesia, and others are just different terms. However, substantially all of them lead to the need for fiqh suitable for Indonesian society, namely fiqh of the archipelago.

\section{The Challenge of Fiqh al-Muwatanah}

The idea of not referring to non-Muslim citizens as infidel and replacing it with al-muwätinūn is exciting because, at the same time, there is a strengthening of cases of intolerance in society. Based on data released by the Setara Institute, in 2020, there were 422 violations of religious freedom violations that occurred in Indonesia. Of these, 238 cases were committed by state actors, and 184 cases were committed by non-state actors, such as citizen groups, individuals, and community organizations. ${ }^{67}$

The Regional Government and the Police are the highest offenders in the state actor category with 42 cases each. Meanwhile, the highest non-state actors were citizens with 67 cases and religious organizations with 42 cases. Most non-state actors committed

${ }^{65}$ Masdar F. Mas'udi, Agama Keadilan: Risalah Zakat (pajak) dalam Islam, Edisi ke-3 (Jakarta : P3M, 1993).

${ }^{66}$ Mukhish Usman, Kaidah-kaidah Ushuliyyah dan Fiqhiyyah (Jakarta: Gema Insani Press, 2000), 14.

67 SETARA Institute, Siaran Pers Launching Laporan Kondisi Kebebasan Beragama/Berkeyakinan Di Indonesia Tahun 2020 (Jakarta, 6 April 2021). 
violations of religious freedom in the form of intolerance, namely 62 cases, 32 cases of blasphemy of religion, 17 cases of refusing the establishment of places of worship, 8 cases of prohibiting religious activities, 6 cases of destroying places of worship, and 5 cases of violence and rejection of other activities. While the group of victims of KBB violations in 2020 consists of residents (56 incidents), individuals (47), Local Religion/Believers (23), Students (19), Christians (16), Christians (6), State Civil Apparatus (4), Confucians (3), Catholics (3), Muslims (3), Hindus (3), Buddhists (2), and religious organizations (2). ${ }^{68}$

Then, based on the results of research conducted in 2014-2019, the Setara Institute ranked violations of freedom of religion and belief in regions in Indonesia. West Java was the top with 162 cases, DKI Jakarta 113 cases, East Java 98 cases, Central Java 66 cases, Aceh 65 cases, Yogyakarta 37 cases, Banten 36 cases, North Sumatra 28 cases, South Sulawesi 27 cases, and West Sumatra 23 cases. ${ }^{69}$ In 2020, the Setara Institute also created an index of the most tolerant cities in Indonesia. From the index, it is known that the 10 cities with the lowest scores are Pasuruan, Depok, Padang, Pangka Pinang, Surakarta, Banda Aceh, Bandung, Medan, Makassar, and DKI Jakarta. More details can be seen through the following table:70

\begin{tabular}{|c|c|c|}
\hline Ranking & City & Skore \\
\hline 85 & Pasuruan & 4,00 \\
\hline 86 & Depok & 2,00 \\
\hline 87 & Padang & 2,00 \\
\hline 88 & Pangka Pinang & 1,00 \\
\hline
\end{tabular}

68 Ibid.

69 JPPN News, “Daftar Provinsi Intoleran berdasar Hasil Riset SETARA Institute", jppn.com, release 24 Nopember 2019, https:/ /www.jpnn.com/news/daftarprovinsi-intoleran-berdasar-hasil-riset-setara-institute, diakses 03 Agustus 2021.

${ }^{70}$ Subhi Azhari dan Halili, Indeks Kota Toleran (IKT) Tahun 2020..., 45. 


\begin{tabular}{|c|c|c|}
\hline 89 & Surakarta & 1,00 \\
\hline 90 & Banda Aceh & 1,00 \\
\hline 91 & Bandung & 1,00 \\
\hline 92 & Medan & 1,00 \\
\hline 93 & Makassar & 1,00 \\
\hline 94 & DKI Jakarta & 1,00 \\
\hline
\end{tabular}

Furthermore, the Indonesian Survey Institute (LSI) released the results of a survey conducted on September 8-17, 2019, to 1,550 Muslim respondents. The release stated that 59.1 percent of Muslim respondents objected to being led by parties of different faiths. Meanwhile, 31.3 percent of Muslim respondents have no problem if non-Muslims lead them. The survey results also stated that 53 percent of Muslims objected to those with different beliefs building a house of worship, and 36.8 percent said they did not mind. ${ }^{71}$

Based on this data, there are still many cases of violations and intolerance in Indonesia. Of course, this is a separate agenda that must be resolved. The factors that cause the emergence of intolerance are, $^{72}$ first, social and economic factors. The poverty factor that afflicts specific individuals or groups is assessed as the primary variable that makes a significant contribution to violence and intolerance. Prolonged social conflict also contributes to intolerance and violence; second, government performance factors, such as poor governance or poor governance; rampant corruption, the development of a culture of impunity for violations of the law by the state and its apparatus as well as a repressive attitude under the pretext of national stability, limitation of space for public participation, closure of access to power, and others; third, mental-psychological factors, such as an

${ }^{71}$ JPPN News, “Survei LSI: Mayoritas Muslim Indonesia Intoleran dalam Urusan Politik", jppn.com, release 03 Nopember 2019, https:/ / www.jpnn.com/news/survei-lsimayoritas-muslim-indonesia-intoleran-dalam-urusan-politik, diakses 03 Agustus 2021.

72 Didin Syafruddin dan Ismatu Ropi (Ed.), Gen Z: Kegalauan Identitas Keagamaan (Jakarta: PPIM-UIN Jakarta, 2018), 24. 
impulsive attitude, thrill-seeking behavior or the desire for revenge, and responses to insults; fourth, radical religious understanding. The religious ideology, which contains many values that tend to be intolerant and contain violence, will direct its adherents to take any action or action which is an expression of the values it contains. ${ }^{73}$

By looking at the facts above, it is necessary to think of solutions to overcome the growing violence and intolerance. Frost, in Democracy and Toleration, as quoted by Zaini argues, there are two perspectives on tolerance, namely a conception based on state authority (permission concept) and a conception based on culture and a willingness to understand and respect each other (respect concept). ${ }^{74}$ The first, permission conception, is that the state gives tolerance or permission to minorities to live according to their beliefs as long as it does not question the domination of the ruler (or majority). ${ }^{75}$ The primary weakness of Frost's opinion is that the terminology of majority and minority is still emerging. In contrast, tolerance is built if all are on the same principle, namely equality and justice. Here, the state can make rules that close the space for their violent and intolerant attitudes by implementing the rule of law fairly and equally. The second, respect conception, is that tolerance must build mutual understanding and respect in ethnic, religious, racial, and linguistic diversity. Here religious leaders (teachers, kyai, priests, and others) have an essential role in educating the public

73 Zuli Qodir, "Kaum Muda, Intoleransi, dan Radikalisme Agama”, Jurnal Studi Pemuda, Vol. 5, No. 1, Mei 2016, 432, https://doi.org/10.22146/studipemudaugm.37127

74 Zaini, "Penguatan Pendidikan Toleransi Sejak Usia Dini (Menanamkan Nilai-Nilai Toleransi Dalam Pluralisme Beragama Pada Pendidikan Anak Usia Dini (Paud) di Kabupaten tulungagung Tahun 2010)", Toleransi: Media Komunikasi Ilmiah Umat Beragama, Vol 2, No 1 (2010), 20, http:/ / dx.doi.org/10.24014/trs.v2i1.423

75 Muhammad Nur Prabowo Setyabudi, “Konsep dan Matra Konsepsi Toleransi dalam Pemikiran Rainer Forst", Jurnal Filsafat Indonesia, Vol 3 No 3 Tahun 2020, 89, http://dx.doi.org/10.23887/jfi.v3i3.24895 
about the importance of togetherness, peace, respect for other groups by utilizing existing media, such as the internet, social media, or others. Radicals use the internet and social media for agitation and propaganda. A study conducted by Jennifer Yang Hui shows that the website is the most widely used medium by radical groups. ${ }^{76}$ Not only through the website but the propaganda of this radical group also utilizes social media. ${ }^{77}$ This phenomenon must be balanced by increasing content on the internet and social media about religious tolerance and non-violence, as did Gus Baha'. Gus Baha' can be a balancer and even an alternative that offers a tolerant, easy, and uncomplicated Islam. ${ }^{78}$

In more detail, Zuli Qodir explained that four things could be done to prevent violence and intolerance from happening; ${ }^{79}$ first, psychological preparation, especially for the young group. The younger generation is the group most susceptible to intolerance or radicalism. Marc Sageman, as quoted by Didin Syafruddin and Ismatu Ropi (Ed.), through his profiling of 172 global jihadists who had been involved in these activities from the 1990s to the early 2000s, showed that the average age of the youth group was 26 at the time. Started to get involved, as many as 115 (70\%) joined and were involved in terrorist movements in other countries (not their place of birth), as many as $14(8 \%)$ were second-generation immigrants in

76 Jennifer Yang Hui, "The Internet in Indonesia: Development and Impact of Radical Websites," Studies in Conflict \& Terrorism 33, no. 2 (January 21, 2010), 16, https://doi.org/10.1080/10576100903400605

77 Asep M. Iqbal, "Internet, Identity and Islamic Movements: The Case of Salafism in Indonesia," Islamika Indonesiana 1, no. 1 (June 7, 2014), 81-105, https:// doi.org/10.15575/isin.v1i1.42

78 Saifuddin Zuhri Qudsy dan Althaf Husein Muzakky, “Dinamika Ngaji Online Dalam Tagar Gus Baha (\#Gusbaha): Studi Living Qur'an di Media Sosial", Poros Onim, Volume 2, Nomor 1, Juni 2021, 13-15, https://doi.org/10.53491/porosonim.v2i1.48

79 Zuli Qodir, “Kaum Muda, Intoleransi, dan Radikalisme Agama..., 436-437. 
England, France, and America; 80 second, opening up political access space. Not a few of the emergence of radicalism due to the lack of access for the community. Studies have shown that a country increasingly provides opportunities and access to the same politically for the people and the products of available policies. There is a slight possibility of fighting radically; ${ }^{81}$ third, addressing economic inequality. Weak economic conditions can lead to perceptions of being mistreated by the State/government. These conditions can become targets for recruiting radical groups by taking advantage of disappointment and anger because of unfair treatment. Overcoming economic inequality can be done by creating jobs, capital, and others. ${ }^{82}$ The research results in Europe show that people involved in radical groups from an economic point of view are at the lower class level 52 people and middle class 36 people out of a total of 93 radical people. In terms of employment, 30\% of the 126 people arrested are arrested are unemployed; 83 fourth, providing religious understanding that is tolerant and non-violent. The role of religious leaders becomes essential in providing understanding and encouraging the emergence of tolerance, and reinterpreting texts that can be misunderstood is a must so that religion can be felt like mercy (tenderness, compassion, and gentleness) ${ }^{84}$ for humans. Religion is one of the values that can encourage its adherents to be good. As a value, religion becomes the glue of beliefs or feelings that give a pattern to its adherents' thoughts, feelings, and behavior. ${ }^{85}$ In this context, education is an essential means of creating tolerant beliefs,

80 Didin Syafruddin dan Ismatu Ropi (Ed.), Gen Z: Kegalauan Identitas Keagamaan..., 32-34.

${ }^{81}$ Ibid., 29.

82 Ibid., 26.

${ }^{83}$ Ibid., 34.

${ }^{84}$ Abi Husain Ahmad Ibn Faris Ibn Zakariya, Mu'jam Maqayisu al-Lughati li tahqiq Abd al-Salam Muhammad Harun, Vol. 2 (Beirut: Dar al-Fikr, 1979), 498.

85 Zakiah Darajat, Dasar-Dasar Agama Islam (Jakarta: Bulan BIntang 1980), 260. 
attitudes, and behaviors in life. ${ }^{86}$ Mukti Ali mentioned the need to agree in disagreement, which believes that religion is best, and invite others to believe that religion is a religion that embraced the most good. It is believed that between one religion and another, apart from differences, there are also similarities. ${ }^{87}$

Thus, the challenges of figh al-muwātanah are indeed weighty, long, and winding. Requires the commitment and cooperation of all elements of the nation to continuously "campaign" tolerance, equality, and justice in the life of the nation and state. By prioritizing the pattern of da'wah that is characteristic of NU, as explained by Ahmad Shiddiq, namely tawassut (moderate), i'tidāl (upright), tasammuh (tolerant), and tawāzun (balanced), 88 makes NU has a characteristic and a different face from other organizations. ${ }^{89} \mathrm{NU}$ is an organization with high flexibility to continue to build the nation with the government. Although not infrequently, NU can also take a tough stance against the government when tolerance, equality, and justice are ignored. ${ }^{90}$ As the most significant religious organization in Indonesia, NU can play a massive cultural role in society. With institutional potential from the center to remote corners of the country, it is easier for NU to empower the community. Coupled with many NU scholars and intellectuals, this is the most potent ammunition in building tolerance in Indonesia.

${ }^{86}$ Mahfud Junaedi, Ilmu Pendidikan Islam Filsafat Dan Pengembangan (Semarang: Rasail, 2010), 182.

${ }^{87}$ Febri Handayani, "Toleransi Beragama dalam Perspektif HAM di Indonesia”, Toleransi: Media Komunikasi Ilmiah Umat Beragama, Vol 2, No 1 (2010), 71, http://dx.doi.org/10.24014/trs.v2i1.426

88 Ahmad Najib Burhani, "Al-Tawassut wa-l I'tidāl: The NU and Moderatism in Indonesian Islam", Asian Journal of Social Science, 40 (2012), 570. DOI: 10.1163/1568531412341262

${ }^{89}$ Muhammad Makmun Rasyid, "Islam Rahmatan Lil Alamin..., 105.

90 Saiful Mujani and R. William Liddle, "Muslim Indonesia's Secular Democracy", Survei Asia, Vol. 49, Edisi 4, 2009, 587. DOI: AS.2009.49.4.575 
Figh Al-Muwātanah: Nahdlatul Ulama's Interpretation About Citizenship

\section{CONCLUSION}

Fiqh al-muwātanah offered by NU is a perspective that forms the basis for all citizens that humans are the same without differences; there is no majority or minority. What applies is the principle of equality before the law. The concept of Figh al-muwātanah becomes a balancer and even alternative in strengthening radical groups or takfirism in Indonesia, which often commit acts of violence and intolerance towards other groups.

Historically, the emergence of figh al-muwattanah shows the consistency of NU in guarding the Unitary State of the Republic of Indonesia based on Pancasila and the 1945 Constitution. The challenge ahead in implementing figh al-muwattanah is the still radical solid group that demands the formalization of religion in the state. However, this is not impossible with NU's strengths, such as the organizational structure from the center to the regions, plus the number of ulama and intellectuals.

\section{DAFTAR PUSTAKA}

Azhari, Subhi dan Halili. Indeks Kota Toleran (Ikt) Tahun 2020 (Jakarta: Pustaka Masyarakat Setara, 2020.

Badan Pusat Statistik (BPS). Kewarganegaraan, Suku Bangsa, Agama, dan Bahasa Sehari-hari Penduduk Indonesia Hasil Sensus Penduduk 2010. Jakarta: Badan Pusat statistic, 2010.

Burhani, Ahmad Najib. "Al-Tawassuṭ wa-l I'tidāl: The NU and Moderatism in Indonesian Islam”, Asian Journal of Social Science, 40 (2012), 570. DOI: 10.1163/15685314-12341262

Bruinessen, Martin Van. NU: Tradisi, Relasi-relasi Kuasa, Pencarian Wacana Baru. Yogyakarta: Elkis,1994.

CNN Indonesia News. "Berasal dari Alquran, Kata 'Kafir' Bukan Bentuk Penghinaan pada Non-Muslim, cnnindonesia.com, 
Realease

https:// www.cnnindonesia.com/nasional/2019030216512432-374019/ fui-sebut-fatwa-nu-non-muslim-bukan-kafirbermotif-politis.

Dahlan, Abdul Aziz (et.al). Ensiklopedi Hukum Islam, Jilid 3. (Jakarta: Ichtiar van Hoeve, 1996.

Darajat, Zakiah. Dasar-Dasar Agama Islam. Jakarta: Bulan Bintang 1980.

Effendy, Bahtiar. Re-Politisasi Islam: Pernahkah Islam Berhenti Berpolitik?. Bandung: Mizan, 2000.

Esack, Farid. Membebaskan Yang Tertindas: Alquran, Liberalisme, Pluralism, Terj. Watung A. Budiman. Bandung: Mizan, 2000.

Fitriani, dan Siti Aisyah. "Konsep Kafir dalam Pandangan Nahdlatul Ulama (NU) dan Forum Umat Islam (FUI) Sumatera Utara", Studia Sosia Religia, Volume 2 Nomor 2, Juli-Desember 2019: 37, 288-289. http://dx.doi.org/10.51900/ssr.v2i2.6485

Ghazali, Abd. Rohim. "Kerukunan Antarumat dan Peran Ulama" dalam Andito (ed.), Atas Nama Agama: Wacana Agama dalam Dialog "Bebas" Konflik. Bandung: Pustaka Hidayah,1998.

Hadi, Sutrisno. Metodologi Research I. Yogyakarta: Yayasan Penerbit Fak. Psikologi UGM, 1995.

Haidar, M. Ali. Nahdatul Ulama dan Islam di Indonesia, Pendekatan Fiqih dalam Politik. Jakarta: Gramedia, 1998.

Handayani, Febri. “Toleransi Beragama dalam Perspektif Ham Di Indonesia", Toleransi: Media Komunikasi Ilmiah Umat Beragama, Vol 2, No 1 (2010): 71. http:/ / dx.doi.org/10.24014/trs.v2i1.426

Haq, Fajar Riza U1. "Sambutan Maarif Institut", Fikih Kebinekaan. Bandung: Mizan Media Utama, 2015. 
Haryanto, Sri. "Pendekatan Historis dalam Studi Islam", Manurul Qur'an: Jurnal Ilmiah Studi Islam, VOL 17 NO 1 (2017), 131, https://doi.org/10.32699/mq.v17i1.927

Hassan, Ahmad. Islam dan Kebangsaan, dalam Tiar Anwar Bachtiar (ed.), Risalah Politik A. Hassan. Jakarta: Pembela Islam Media, 2013.

Hawa, Said. al-Islam, Terj. Abdul Hayyi al-Kattani, dkk. Jakarta: Gema Insani Press, 2004.

Hazairin. Hukum Kewarganegaraan Nasional, Edisi ke-3. Jakarta: Tintamas, 1982.

Hitti, Philip K. History of the Arabs. London: The MacMillan Press, 1974.

Hui, Jennifer Yang. "The Internet in Indonesia: Development and Impact of Radical Websites," Studies in Conflict E Terrorism 33, no. 2 (January 21, 2010): 16. https:// doi.org/10.1080/10576100903400605

Iqbal, Asep M. "Internet, Identity and Islamic Movements: The Case of Salafism in Indonesia," Islamika Indonesiana 1, no. 1 (June 7, 2014): 81-105. https:// doi.org/10.15575/isin.v1i1.42

Izutsu, Toshihiko. Konsep Kepercayaan dalam Teologi Islam. Yogyakarta: Tiara Wacana Yogya, 1994.

JPPN News. "Daftar Provinsi Intoleran berdasar Hasil Riset SETARA Institute", jppn.com, release 24 Nopember 2019, https://www.jpnn.com/news/daftar-provinsi-intoleranberdasar-hasil-riset-setara-institute.

------.. "Survei LSI: Mayoritas Muslim Indonesia Intoleran dalam Urusan Politik", jppn.com, release 03 Nopember 2019, https:// www.jpnn.com/news/survei-lsi-mayoritas-muslimindonesia-intoleran-dalam-urusan-politik.

Junaedi, Mahfud. Ilmu Pendidikan Islam Filsafat Dan Pengembangan. Semarang: Rasail, 2010. 
Karna News. "M. Din Syamsuddin: Seputar Polemik Tentang Kafir", karna.id, Release 7 Maret 2019, https://karna.id/m-dinsyamsuddin-seputar-polemik-tentang-kafir/.

Kompas News. "NU Usul Non-Muslim di Indonesia Tak Disebut Kafir", kompas.com, Received 01 Maret 2019, https://regional.kompas.com/read/2019/03/01/12404031/n u-usul-non-muslim-di-indonesia-tak-disebut-kafir?page=all .

Maarif, Ahmad Syafii. Islam dan Pancasila sebagai sebagai Dasar Negara, Studi tentang Perdebatan dalam Konstituante. Jakarta: Pustaka LP3ES, 2006.

Madjid, Nurcholis. "Menyegarkan Paham Keagamaan di Kalangan Umat Islam Indonesia," dalam Islam, Kemoderenan dan Keindonesiaan. Bandung: Mizan, 1987.

Mahfud, Salah. Solusi Hukum Islam: Keputusan Muktamar, Munas dan Konbes NU 1926-2004, Cet. III. Kudus: Khalista, 2007.

Malik, Dedy Djamaluddin dan Idi Subandy Ibrahim. Zaman Baru Islam Indonesia; Pemikiran dan Aksi Politik Abdurrahman Wahid, M. Amien Rais, Nurcholis Madjid, Jalaluddin Rakhmat, Cet. 1. Bandung: Zaman Wacana Mulia, 1998.

Mas'udi, Masdar F. Agama Keadilan: Risalah Zakat (pajak) dalam Islam, Edisi ke-3. Jakarta: P3M, 1993).

Medcom News. "JK: Nonmuslim Sebutan Lembut Kafir, medcom.id, Release 12 Maret 2019, https:// www.medcom.id/nasional/peristiwa/Obzqy4dN-jknonmuslim-sebutan-lembut-kafir.

Mietzner, Marcus and Burhanuddin Muhtadi. "The Myth of Pluralism: Nahdlatul Ulama and the Politics of Religious Tolerance in Indonesia," Contemporary Southeast Asia: A Journal of International and Strategic Affairs, Vol. 42, No. 1 (April 2020), 64-65. DOI: $10.1355 /$ cs42-1c

Mu'in, M. Taib Thahor Abdul. Ilmu Kalam. Jakarta: Widjaya, 1997. 
Muhajir, Afifudin. “Meneguhkan Islam Nusantara untuk Peradaban Indonesia dan Dunia", makalah disampaikan pada Seminar Pra Muktamar NUke-33 di Asrama Haji Makassar, 22 April 2015.

Muharam, Ricky Santoso. “Membangun Toleransi Umat Beragama Di Indonesia Berdasarkan Konsep Deklarasi Kairo (Creating Religion Tolerance in Indonesia Based on the Declaration of Cairo Concept)", Jurnal HAM, Volume 11, Nomor 2, Agustus 2020: 270. http:/ / dx.doi.org/10.30641/ham.2020.11.269-283

Mulia, Musda. "Negara Islam - Pemikiran Politik Husain Haikal”. Disertasi--IAIN Syarif Hidayatullah, Jakarta 1997.

Mujani, Saiful and R. William Liddle. "Muslim Indonesia's Secular Democracy," Survei Asia, Vol. 49, Edisi 4, 2009, 587. DOI: AS.2009.49.4.575

PTIQ News. "Polemik Kafir Atau Non Muslim Terjawab Dalam Seminar Nasional di Institut PTIQ Jakarta", ptiq.ac.id, Received 14 Maret 2019, https://ptiq.ac.id/2019/03/15/polemik-kafiratau-non-muslim-terjawab-dalam-seminar-nasional-diinstitut-ptiq-jakarta/.

Qardawi (al), Yusuf. Pedoman Bernegara Dalam Perspektif Islam, Terj. Kathur Suhadi. Jakarta: Pustaka Al Kautsar, 1999.

Qodir, Zuli. "Kaum Muda, Intoleransi, dan Radikalisme Agama", Jurnal Studi Pemuda, Vol. 5, No. 1, Mei 2016: 432, 436-437. https:// doi.org/10.22146/studipemudaugm.37127

Qudsy, Saifuddin Zuhri dan Althaf Husein Muzakky. “Dinamika Ngaji Online Dalam Tagar Gus Baha (\#Gusbaha): Studi Living Qur'an di Media Sosial", Poros Onim, Volume 2, Nomor 1, Juni 2021: 13-15. https:/ / doi.org/10.53491/porosonim.v2i1.48

Rasyid, Muhammad Makmun. "Islam Rahmatan Lil Alamin Perspektif KH. Hasyim Muzadi", Episteme, Vol. 11, No. 1, Juni 2016: 107. https:/ / doi.org/10.21274/epis.2016.11.1.93-116 
Republika News. “Said Aqil Jelaskan Perbedaan Kafir dan Non-Muslim, republika.or.id, Release, 01 Maret 2019, https://www.republika.co.id/berita/pnogps409/said-aqiljelaskan-perbedaan-kafir-dan-nonmuslim.

Sahal, Ahmad. Islam Nusantara, dari Ushul Figh hingga Paham Kebangsaan. Bandung: Mizan, 2015.

Said, Imam Ghazali. “Intelektualitas KH Afifuddin Muhajir", dalam KH. Afifuddin Muhajir: Faqih Ushuli dari Timur, Abdul Moqsith Ghazali (Penyinting). Malang: Inteligensia Media, 2021.

Salim, M. Arskal. Challenging The Secular State: The Islamization of Law in Modern Indonesia. Hawai'i: University of Hawai'i Press, 2008.

Samuddin, Rapung. Fiqih Demokrasi. Jakarta: Gozian Press, 2013.

SETARA Institute. Siaran Pers Launching Laporan Kondisi Kebebasan Beragama/Berkeyakinan Di Indonesia Tahun 2020 (Jakarta, 6 April 2021).

Saenong, Faried F. "Nahdlatul Ulama (NU): A Grassroots Movement Advocating Moderate Islam," in Handbook of Islamic Sects and Movements, Ed. Muhammad Afzal Upal and Carole M. Cusack. Published by Brill, 2021.

Setyabudi, Muhammad Nur Prabowo. “Konsep dan Matra Konsepsi Toleransi dalam Pemikiran Rainer Forst", Jurnal Filsafat Indonesia, Vol 3 No 3 Tahun 2020: 89. http:/ / dx.doi.org/10.23887/jfi.v3i3.24895

Shiddieqy, Hasbi Ash. Syari'at Islam Menjawab Tantangan Zaman. Yogyakarta: IAIN Sunan Kalijaga, 1961.

Sholihuddin, Muh. "Kontruksi Fikih Kebangsaan Nahdlatul Ulama (Kajian terhadap Peran NU dalam Perspektif Fiqh Siyasah)", Al-Qanun: Jurnal Pemikiran dan Pembaharuan Hukum Islam, Vol. 24, No. 1, Juni 2021.

Siradj, Said Aqil. Islam Kebangsaan; Figh Demokratik Kaum Santri. Jakarta: Pustaka Ciganjur, 1999. 
Sjadzali, Munawir. "Reaktualisasi Ajaran Islam", dalam Polemik Reaktualisasi Ajaran Islam, ed., Iqbal Abdurrauf Sainima. Jakarta: Pustaka Panjimas, 1980.

Suara News. "Pro Kontra Penghapusan Panggilan Kafir untuk Non Muslim", Suara.com, Release 07 Maret 2019, https://www.suara.com/news/2019/03/07/073000/prokontra-penghapusan-panggilan-kafir-untuk-nonmuslim?page=all.

Sulaiman, Ibnu. Anda Muslim atau Kafir?, cet. 2. Jakarta: Arista,1994.

Syafruddin, Didin dan Ismatu Ropi (Ed.). Gen Z: Kegalauan Identitas Keagamaan. Jakarta: PPIM-UIN Jakarta, 2018.

Syeirazi, M. Kholid. "Tentang Non-Muslim Bukan Kafir", nu.co.id, Release, $02 \quad$ Maret 2019, https:// www.nu.or.id/post/read/103224/tentang-nonmuslim-bukan-kafir.

Tirto News. "Kata Pemuda Muhammadiyah Soal Usul NU Tak Sebut Kafir ke Non-Islam", Tirto.id, Release 1 Maret 2019, https:/ / tirto.id/kata-pemuda-muhammadiyah-soal-usul-nutak-sebut-kafir-ke-non-islam-didc.

Usman, Mukhish. Kaidah-kaidah Ushuliyyah dan Fiqhiyayah. Jakarta: Gema Insani Press, 2000.

Wahid, Abdurrahman. Islamku, Islam Anda, Islam Kita. Jakarta: Wahid Institute, 2006.

Wahid, Wawan Gunawan Abdul dkk. Fikih Kebhinekaan. Bandung: Mizan Pustaka, 2015.

Zaini. "Penguatan Pendidikan Toleransi Sejak Usia Dini (Menanamkan Nilai-Nilai Toleransi Dalam Pluralisme Beragama Pada Pendidikan Anak Usia Dini (Paud) di Kabupaten tulungagung Tahun 2010)", Toleransi: Media Komunikasi Ilmiah Umat Beragama, Vol 2, No 1 (2010): 20. http:/ /dx.doi.org/10.24014/trs.v2i1.423 
Zakariya, Abi Husain Ahmad Ibn Faris Ibn. Mu'jam Maqayisu alLughati li tahqiq Abd al-Salam Muhammad Harun, Vol. 2 (Beirut: Dar al-Fikr, 1979.

Yunis, Mohammed Politik Pengkafiran dan Petaka Kaum Beriman, Terj. Dahyal Afkar. Yogyakarta: Nuansa Aksara, 2006.

Yunus, Mahmud. Kamus Arab Indonesia. Jakarta: Yayasan Penyelenggara Penterjemah Pentafsir al-Qur'an, 1973. 